Illinois State University

ISU ReD: Research and eData

Theses and Dissertations

$12-2009$

\title{
Impact of Microfinance and Remittances on the Livelihood of Nepali People
}

Bishal B. Kasu

Illinois State University

Follow this and additional works at: https://ir.library.illinoisstate.edu/etd

\section{Recommended Citation}

Kasu, Bishal B., "Impact of Microfinance and Remittances on the Livelihood of Nepali People" (2009). Theses and Dissertations. 281.

https://ir.library.illinoisstate.edu/etd/281

This Thesis is brought to you for free and open access by ISU ReD: Research and eData. It has been accepted for inclusion in Theses and Dissertations by an authorized administrator of ISU ReD: Research and eData. For more information, please contact ISUReD@ilstu.edu. 


\title{
IMPACT OF MICROFINANCE AND REMITTANCES ON THE LIVELIHOOD OF NEPALI PEOPLE
}

\author{
Bishal B. Kasu
}

52 Pages

December 2009

This quantitative study used the Nepal Living Standard Survey 2003/04 data to examine the impact of microfinance and remittances on the livelihood of Nepali people.

APPROVED:

Date

Frank D. Beck, Chair

Date

Ali Riaz

Date

Winfred Avogo 


\title{
IMPACT OF MICROFINANCE AND REMITTANCES ON THE LIVELIHOOD OF NEPALI PEOPLE
}

\author{
Bishal B. Kasu
}

52 Pages

December 2009

This research is about the impact of microfinance and remittances on the livelihood of Nepali people. The research has adopted a quantitative approach and used the Nepal Living Standard Survey 2003-04 dataset. The research shows that microfinance and remittances have a clear effect on percent of expenses made on food, health, education, and the housing quality of Nepali people.

Out of four dependent variables, microfinance is significantly associated with percent of expenses on food, health and housing quality. Amount of microfinance loans received is negatively associated with percent of expenses on food and quality of housing but positively associated with the percent of expense on health. Similarly, remittances are significantly associated with two livelihood variables - food and education, but in an opposite direction. It has a negative association with food and a positive association with child education. The significant association of remittances with percent of children currently attending school shows that improvement in the financial situation of the household has a positive impact on education of children. 
Out of all independent variables, the total number of household jobs is the only variable which is significantly and negatively associated with all four dependent variables. Interestingly, household income is the weakest independent variable. It is significantly and negatively related with food only. Income has no significant relationship with health, education or housing. Income is overshadowed by other stronger factors like education level of the household head, caste and ethnicity, sex of household head, marital status of household head and number of dependent persons in the household. These variables are significantly associated with food, education and housing. It may indicate that Nepal is still a traditional country, where social factors are stronger than economic factors.

\section{APPROVED:}

Date Frank D. Beck, Chair

Date Ali Riaz

Date Winfred Avogo 


\section{IMPACT OF MICROFINANCE AND REMITTANCES ON THE LIVELIHOOD OF}

NEPALI PEOPLE

BISHAL B. KASU

A Thesis Submitted in Partial Fulfillment of the Requirements for the Degree of

MASTER OF ARTS

Department of Sociology and Anthropology

ILLINOIS STATE UNIVERSITY

2009

IMPACT OF MICROFINANCE AND REMITTÁNCES ON THE LIVELIHOOD OF NEPALI PEOPLE 
BISHAL B. KASU

THESIS APPROVED:

\begin{tabular}{ll}
\hline Date & Frank D. Beck, Chair \\
& \\
\hline Date & Ali Riaz \\
& \\
\hline Date & Winfred Avogo
\end{tabular}




\section{ACKNOWLEDGMENTS}

I have completed this thesis with the help of many friends, family members, and mentors. It would have been impossible to finish this work without their timely help, suggestions, and guidance. First of all, I would like to thank my thesis committee. I am blessed to have such experienced, knowledgeable, and cooperative members on my thesis committee. I am deeply indebted to Dr. Frank Beck for his guidance, suggestions, and continuous encouragement. He has sacrificed several hours of his personal, family time assisting me. Dr. Beck, I do not believe that I can ever return the support that you have provided to me in any form. I am deeply indebted, respectful, and proud of being your disciple. I am also thankful to Dr. Ali Riaz and Dr. Winfred Avogo for their suggestions, genuine concerns, and continuous back up. Their deep knowledge of development directly and positively shaped my thesis.

I am grateful to Dr. MariBeth Welch, Chief Operations Officer and my supervisor, at ASPIRA Inc. of Illinois, Chicago IL. She has taken a true interest in my thesis and always encouraged me, which helped me to meet my thesis deadline. She was always supportive of my travel schedule, sometimes on short-notice, needed for my thesis

work. Dr. Welch, this thesis would have been nearly impossible without your support and generosity.

I would like to thank my cousin, Biswas Palikhe, who helped acquire the NLSS dataset available from the Central Bureau of Statistics, Kathmandu, Nepal. I would also 
like to thank my friend, Shiva Shrestha, and Tirtha Chaulagain, Statistics Officer CBS Nepal, for their timely help.

My family members have been the most impacted by my decision to pursue my further education abroad. The decision was sudden, self-centered, and was taken without consultation with any family members. I am thankful to my father, Bhakta Bahadur Shrestha (Kasu), and my mother, Bidhya Palikhe (Kasu), who happily allowed me to go far away from them. My parents are the most respected persons in my life. They instilled me the importance of education and taught me to live life with values.

During my educational endeavor, the wisest persons whom I ever met are my two lovely daughters, Bidhi Kasu and Bija Kasu. They were always careful, sensitive, and supportive of my studies. At this point, I would like to thank three families: Phil and Diane Tetley, Jim and Lisa Lavender, and John and Linda Burger, whose love and support made our stay in Normal very enjoyable and memorable. And last, but most importantly, throughout the course of my educational pursuits, the most affected person was, and still is, my wife, Bijaya Pradhan (Kasu). My education at Illinois State University and this thesis would not have been possible without her continuous support and encouragement. Besides all other factors, her care, thoughtfulness, and love were decisive in the completion of my work.

Being thankful to all of you, I acknowledge that the insight and knowledge that I have gained during this process are invaluable to me. I can only hope that I can make some positive changes in some ways, and somewhere, in the lives of the poor and disadvantaged people in the world.

B.B.K. 


\section{CONTENTS}

\section{Page}

ACKNOWLEDGMENTS

CONTENTS

iii

TABLES

iv

CHAPTER

I. INTRODUCTION

Introduction 1

Nepal in Brief 3

Microfinance and Remittance 4

Two phrases and two approaches 4

Microfinance, women and livelihoods 6

Migration and remittance 8

Remittance and livelihood 9

Nepal, microfinance and remittance $\quad 10$

Research Methodology 13

Sample Design 13

Sample Frame 14

Survey Questionnaire $\quad 15$

Key Variables $\quad 15$

Socioeconomic variables $\quad 16$

Household demography $\quad 17$

Region $\quad 17$

Dependent variables $\quad 17$

$\begin{array}{ll}\text { Summary/Conclusion } & 27\end{array}$

II. REVIEW OF LITERATURE

Microfinance $\quad 34$

$\begin{array}{ll}\text { Remittance } & 40\end{array}$

$\begin{array}{ll}\text { REFERENCES } & 47\end{array}$ 


\section{TABLES}

Table

Page

1.

criptive Statistics for Independent and Dependent

Variables

Des

19

2.

Corr

elations among Dependent Variables

3.

Dep

endent Variable is Percent of Expenses on Food

30

4.

Dep

endent Variable is Percent of Expense on Health

5. Dependent Variable is Percent of Children 5-18 currently Attending School

6.

Dep

endent Variable is Quality of Housing

33 


\section{CHAPTER I}

Introduction

In the 1970s, microfinance emerged from research experiment of Professor Muhammad Yunus in Bangladesh. He used to provide small loans to rural women using their social network as collateral. With time this idea turned out to be a revolutionary and spread around the world. Existing banks did not give loans to poor. The provision of collateral as security forced poor people to be excluded from traditional banking. Microfinance allows the poor to access loans from financial institutions. More than 100 million of the poorest families in the world are getting microloans, which is affecting the lives of more than 533 million people (Harris 2009). These people reside mostly in developing countries. Today microfinance is one of the most effective and the most popular tools against poverty. Many countries including Nepal include microfinance in their development plan to reduce poverty.

Nepal has launched several programs, including microfinance, to address poverty. In 1975 the Nepal Agriculture Development Bank introduced a microfinance program, the Small Farmer Development Project, targeting poor farmers (Shrestha 2003; Uprety 2008). It was a part of the "Deprived Sector Regulation" that was common in all developing countries at that time (Rankin 2001). This regulation forced commercial banks to make loans available to the disadvantaged poor people in rural areas. In the 1990s, under a Structural Adjustment Program, the major responsibilities of the 
microcredit program shifted from commercial banks to Rural Development Banks and non government organizations (NGOs) (Von Pischke et al. 1993; Rankin 2001). Since then the Nepali poor are getting a small amount of credit from many microfinance organizations, development banks, cooperatives and financial intermediaries, NGOs or FINGOs for small enterprises, through which they make their livelihood. However, this funding covers only four percent of the total population and only fourteen percent of the population is under the poverty line (Thapa 2008).

Recently, the inflow of remittances into Nepal has increased significantly. People in Nepal have been involved in both short-term and long-term migration. Migration is a means of livelihood and a good source of income for them. It is helping them fight poverty.

There are two reasons that this thesis focuses on microfinance and remittances. First, both microfinance and remittances are helping the Nepali poor to make ends meet. Second, both are development issues. Income from microfinance and remittances is a financial source. I want to see how Nepali households use financial resources gained by these two methods to create other resources, such as good health, good education, and livelihood skills (human capital).

Hence, some specific questions for this thesis are as follows: How do people use microfinance and money received from remittances for their livelihood? What is the impact of microfinance and remittances on household expense patterns, education of 
children and housing quality? How do socioeconomic, household demographic and geographic factors influence the household level impact of microfinance and remittances?

\section{Nepal in Brief}

Nepal is a small landlocked South Asian country situated in between China and India. Nepal has always been an independent country. The area of the country is 147,181 square kilometers $(56,827 \mathrm{sq} \mathrm{mi})$ and the population is approximately 30 million. Nepal was ruled by Shaha dynasty kings beginning in 1768 . They unified and brought Nepal to its present geographic shape. After the Shaha dynasty the power was held by the Rana dynasty. Both dynasties kept Nepal isolated from the rest of the world. In the 1950s, the first popular movement of the Nepali people overthrew the Rana ruler. Nepal began to implement planned development programs in the 1950s. With this the modern era began in Nepali history. Between the start of the modern era and 2008, Nepal implemented ten development plans. These development plans include vision, goals, objectives and activities five years.

Previous implementation of the development plans has not been effective, resulting in hardly any improvement in the average standard of living. Nepali people are not satisfied and frustrated with the progress of development. Of many, this is one reason behind the beginning of the armed conflict in the leadership of Communist Party of Nepal (Maoist) (Riaz and Basu, 2007). The conflict severely affected the development plans. 
Hence, poverty has become one of the major development challenges. Despite its development efforts, Nepal remains one of the poorest countries in the world.

\section{Microfinance and Remittance}

There are some commonalities and differences between microfinance and remittance. Social capital is the foundation for both. They are operated on the basis of social capital, such as networks, trust, and relationships among people. Microfinance takes people network and trust as mortgage and makes loans against them. Similarly migration functions through people network and trust. People migrate from one place to other through their social connection. The other common feature is their purpose. People become involved in microfinance and remittances to increase household income. There are some gender-based differences. Migration and remittances are dominated by males. Microfinance serves female mostly. Hence, males and females try to increase household income taking two different strategies. Many males migrate and make money for remittances. In other hand, females stay at home, participate in local microfinance programs available in their community, and generate money to support her family.

\section{Two Phrases and Two Approaches}

Two phrases are very common in the discussion of microfinance. They are 'Microfinance' and 'micro credit.' These terminologies maintained some similarities, but 
at the same time they have differences also. Microfinance is a approach, which focuses more on development of a community. It supports community through financial services, e.g. savings, credit and insurance, as well as social services, e.g. empowerment, advocacy, training and solidarity (Qudrat and Rahman 2006; Ledgerwood 1999; Robinson 2002). Microfinance helps poor households and community through strengthening social unity, providing loans, increasing group transparency, and empowerment, especially of women. On the other hand, microcredit is more of a financial program. It provides micro loans and recovers them (Gutberlet 2007). The poor use such microloans for worthy activities for their economic betterment ${ }^{1}$.

Microfinance has two approaches - the social service approach and the business approach (Ledgerwood 1997; Takahatake and Maharjan 2002; Rankin 2001). As its name, the social service approach focuses mainly on the well-being of the poor people. It treats economic development and sustainability as lower priorities. On the other hand, the business approach gives a high priority to economic development and financial sustainability.

Scholars are divided about the best approach to microfinance. Hulme and Mosely (1996) think the social banking approach better serves the poor. But for some like Ledgerwood (1997), the business approach is necessary for effective microfinance and sustainable services. Both arguments are true and valid. For the best result, inclusion of

\footnotetext{
${ }^{1}$ This thesis does not differentiate between microfinance and microcredit.
} 
social well-being of the poor and banking sustainability is necessary. It can be achieved through close coordination between a government welfare program (training, social service, literacy program, or health program) and the business approach of microfinance (Takahatake and Maharjan 2002). The coordination between these two programs allows cost sharing, which could reduce the cost of microfinance. In this way, microfinance could be sustainable and the poor would benefit with social programs without any cost burden. Hence, the coordination is the way to create the condition for long-term sustainable microfinance services for the poor community.

\section{Microfinance, Women and Livelihood}

Mainly women participate in microfinance (Rankin 2001; Stoesz et al 1999; Fisher and Sriram 2002). Women are active, energetic, reliable, productive, as well as contribute more of their income for the social well-being of family members. Women are very responsible and pay loans back (Rankin 2001). Another reason for the higher priority given to women is related to their involvement in household budgeting or budget management. Generally women are responsible for handling household money wisely (Rogaly, Castillo, and Serrano 2004).

Comparatively, the household impact of loans taken by women has a stronger effect on household members than the impact of loans taken by men (Sengupta and Aubuchon 2008). The households in which women are taking loans have better health 
care and child nutrition and better child education (Smith 2002; Khandker 2005). Microfinance helps women to have access and control over the household income and assets (Rogaly, Castillo, and Serrano 2004). However, women in women-headed households enjoy greater control over income and assets in comparison to the women in male-headed households (Padia 2005).

Households which are involved in microfinance experience positive changes (Hulme and Mosley 1996; Simanowitz and Walter 2002; Midgley 2008; Chemin 2008). Involving households in microfinance enhances their income, diversifies their livelihood sources, and increases savings and assets. They can spend more money on food, education and health care. Such households can easily manage food scarcity and health emergencies.

People take microfinance loans for different purposes. Loans can be used for personal or business reasons (Padia 2005; Parthasarathy 2005). Loans can be used in medical treatment, in educational activities, for transportation, or for buying durable goods, such as televisions and radios. Other examples of loans for personal use are maintenance of housing and religious purposes. Loans are equally effective in the opening of small shops, buying agricultural inputs (e.g., seeds, fertilizers), and buying livestock (e.g., goats, poultry, and cows). Poor people also establish small businesses such as flower selling, rope making, grocery shops, and bangle selling using loans from microfinance. 
The literature shows that most of the researchers and professionals agree with the concept that access to microfinance reduces the vulnerability of the households (Develtere and Huybrechts 2005). Microfinance prevents such households from falling further into poverty.

\section{Migration and Remittances}

Migration and remittances are very close and interrelated. Remittances are the economic outcome of the migration. Large amounts of money are flowing from developed to developing and within developing countries through remittances. The direction of remittances and migration is opposite (Coss 2006; Seddon 2004). Generally, remittances flow from developed to developing countries and from urban to rural areas. But opposite of this direction, generally people migrate from the developing to the developed countries. Similarly, urban centers receive a large number of people from rural areas.

Two factors, pushing and pulling, are always active behind the migration (Gill 2003; Seddon et al 2002). The pushing factors, which compel people to move out of their place are poverty, food insecurity, and conflict. Similarly, the people are attracted by (pulling factor) opportunity to work for a higher income. Hence, people use the migration as their rational strategy to maximize the advantage from the existing social as well as economic situation (McDowell and Haan 1997). 


\section{Remittances and Livelihood}

The households and communities that receive remittances, experience a positive impact on the lives of their members (Coss 2006; Ratha 2007; Seddon 2004). The household level impact of remittances differs across countries and socioeconomic groups (Acosta, Fajnzylber and Lopez 2008). Remittances increase the savings rate in poorer households. With the help of remittances received, households can spend more money on the education of household members. Households with low income also observe a positive increment in the educational attainment of their children. Similarly, the remittances improve the health of children in both poor and rich households.

The International Organization for Migration (2006) reports positive impacts of remittances on households. Households can spend remittance for different purposes. They can be spent on food and clothing, medicine, the purchase of land, home construction and repair, repaying loans, marriage and ceremonies, education, telecommunication, savings, funding other people's migration, investment in business and health care (Zarate-Hoyos 2004; Koc and Onan 2004; IOM 2005; Bobeva 2005; Deneulin 2006).

Comparative studies show that households which receive remittances have greater household welfare than households which do not receive remittances (Koc and Onan 2004). Comparatively, the households which receive remittances spend more money on food, durable goods, health, and housing than the households which do not receive remittances (Koc and Onan 2004; Adams, Richard H., Jr. 2006; Airola 2007). Money 
spent by such households is for local enterprise activities. Such households buy more local products. They invest money to establish and run businesses. Investment in local business ultimately generates more opportunities for local business as well as for employees who do not migrate (Bobeva 2005; Adams, Richard H., Jr. 2006).

Nepal, Microfinance and Remittances

In Nepal, microfinance is used as a tool for poverty alleviation. Important government programs which use microfinance are the Intensive Banking Program (IBP), Small Farmers Development Programs (SFDP), Production Credit for Rural Women (PCRW), Micro Credit Project for Women (MCPW), and Grameen Bank. In addition, there are several savings credit organizations, cooperatives and NGOs which run microfinance programs and work with the poor. Interestingly, indigenous Micro Finance Organizations (MFOs) are only sustainable ones and such organizations do not get support from outside. Such organizations are limited only to a few people.

In general, the reasons behind unsuccessful implementation of development programs are weak accomplishment of policy, corruption, low political commitment, poor participation of people, poor management, limited outreach, and difficult geography (Ledgerwood 1997; Bhatta 2001; Dhakal 2006). Other identified problems are a lack of coordination with district government agencies, poor repayment, and the high cost of service delivery (Takahatake and Maharjan 2002). To solve such problems, Ledgerwood (1997) recommends the skill development of professionals who are involved in the 
microfinance sector. She also suggests that the Nepal government should be engaged in wholesale lending rather than retailing programs. In wholesale lending, the Nepal government would lend money to different Micro Finance Organizations which then would be responsible to lend money to citizens.

Migration has been in practice for centuries in South Asia, including Nepal (McDowell and Haan 1997; Seddon et al 2002; Gill 2003; McDowell and Haan 1997). In Nepal, people have been migrating within the country and outside of the country. While there is some movement in the opposite direction, most people migrate from the rural to the urban areas, from the hill to the plain areas, from the west to the east, and from the north to the south part of the country (Seddon et al 2002; Seddon 2004; Gill 2003). India is the favorite and the most accessible country for the international migration. Recently, migration to the Persian Gulf countries, Malaysia, South Korea, Japan, Europe, Australia and America is increasing.

Nepal is getting a large amount of money in remittances. The Nepal Living Standard Survey (2003/04) shows that 32 percent of households received remittances, and the amount of remittance was NRs 46,365,466,726 (CBS 2004). In 2004, the share of remittance was 11.7 percent of the total GDP of Nepal (World Bank 2006).

Though most of the population of Nepal are farmers, the farming alone cannot produce enough income to survive (Seddon 2004). This situation compels people to think over an alternate source of income. In Nepal, for both the higher and the lower caste, migration for work is one of the best sources of income, using their spare time away from 
farming. For the lower caste, the existing caste based inequality is the additional factor for choosing migration (McDowell and Haan 1997). After migrating outside of their society, the untouchables get the economic advantage and can live in a discrimination free environment. For the higher castes, which have a relatively better economic situation than the lower castes, migration is a good way to break the poverty cycle (Gill 2003). However, the irony is that migration does not help very poor families (Seddon et al 2002).

Another dimension to migration in Nepal is length of time (Seddon et al 2002; Gill 2003). Seasonal migration is short term which starts right after planting of rice paddies and exists for four months. All the people who migrated return for the paddy harvest. Generally, men are involved in migration, and women stay home and take care of the chores related to farming such as weeding, irrigating, and putting in fertilizers (Seddon et al 2002). Short term seasonal migration is an every year phenomenon. Long term migration lasts for more than four months, and it is not a yearly activity. Certain ethnic groups in Nepal such as Gurung, Rai, Limbu go for military recruitment in India and the UK and serve there for years. Now, people from the other ethnic groups also go for longer periods as laborers in Malaysia, South Korea, and the Persian Gulf countries. 
Research Methodology

This thesis is based on data derived from the Nepal Living Standard Survey 2003/04. It is based on secondary information. This thesis applies quantitative methods using SPSS.

The Central Bureau of Statistics in Nepal conducted this survey in 2003/04. The first NLSS survey was conducted in 1995/96. The NLSS survey followed the World Bank's Living Standards Measurement Survey (LSMS) methodology, which the World Bank already applied in more than 50 developing countries. This survey is supported by the World Bank and the UK Department for International Development (DFID). Nepal's government conducted this survey for two reasons, which are (a) to monitor the progress in the living standards of people and (b) to evaluate the impact of government policies and programs on the living standards of people.

Sample Design

There are two types of samples within the NLSS II; they are cross-sectional and panel. The cross-sectional sample represents the entire country. This sample is used to see general trends in the living standards of people in the country. Under this sample, 3,912 households were interviewed. The panel sample is from a follow-up interview for those households that already participated in the NLSS I. This sample is designed to see exact changes in the living standards of people over seven years. A total of 1,160 
households were interviewed under this sample. Hence, a total of 5,072 households were interviewed in the NLSS II.

For the NLSS II, there are a total of 421 Primary Sampling Units (PSU), including 326 cross-section PSUs and 95 panel PSUs. From each PSU, 12 households were systematically selected for interviews. The cross-sectional PSUs cover the whole country, which is divided into six strata (i.e., mountains, Kathmandu valley, other urban areas in the hills, rural hills, urban terai and rural terai). These six strata fall under three broader ecological zones - mountain, hill and terai. Out of these three, in NLSS II hill, terai and mountain are in order in terms of the highest to the lowest representation.

The data applied for the thesis analysis is derived from households interviewed in the cross-section sample only (i.e. 3,912 households).

\section{Sample Frame}

The sample frame of the NLSS II uses the 2001 census data. The ward ${ }^{2}$ is the unit of the sample frame. For this survey's purpose, if the ward is larger, it is divided into subwards, and if it is smaller (less than $20 \mathrm{HHs}$ ), the ward is merged with a neighboring ward. There were total of 36,067 enumeration areas (including wards and sub-wards) throughout the country, which includes 3 ecological zones, 5 development regions, 75 districts, 58 Municipalities, and 3,914 Village Development Committees.

\footnotetext{
${ }^{2}$ The ward is the smallest political unit of the country.
} 
Survey Questionnaire

The NLSS II has applied two types of questionnaires; they are household-level and community-level. The household questionnaire seeks household related information such as demographic information, income, expenses, migration patterns, access to facilities, education, health, marriage history, remittances, savings information, and credit information. Similarly, a community-level questionnaire is given to the leader or knowledgeable person of the community and asks questions regarding the access to facilities or services, population characteristics, infrastructure, markets and prices, quality of life, agriculture, and forestry.

Key Variables

There are two key variables in this research - amount of loans taken from microfinance and amount of remittances received. This research analyzes the strength and direction of these key variables with four dependent livelihood variables (percent of expenses on food, percent of expenses on health, percent of children currently attending school and quality of housing) with and without controlling other socioeconomic, household demographic and geographical variables. In average each household takes around NRs 17,000 as loans from microfinance. The average amount of remittances received is nearly NRs 12,000 .

Since, these key variables and income without remittances are skewed; they are log-transformed to make their distributions more normal. 
Socioeconomic Variables

Income, education, number of household jobs and castes and ethnicity are socioeconomic variables. Education is a very important social indicator in any society. In Nepal, the School Leaving Certificate (SLC) is given in $10^{\text {th }}$ grade. The success in SLC only allows students to study further. Hence this study uses two dichotomous variables regarding education of the household head - above SLC and below SLC. Household head with the SLC is the reference group. Most of the household heads $(87 \%)$ are below SLC.

The total number of jobs in the household is also an independent variable. It includes all jobs the household head and non-head perform. The number of jobs in the household varies widely. The minimum number of jobs in a household is 1 and the maximum is 52 .

In Nepal, caste and ethnicity are very important social factors. They touch every walk of life. This thesis examines how caste and ethnicity are related to microfinance and remittances. Caste and ethnicity are divided into seven categories - higher caste, dalit or untouchable, himalayan indigenous ethnic group, hill indigenous ethnic group, inner terai indigenous ethnic group, terai indigenous ethnic group and madhesis. In the analysis all other categories will be compared to dalit - those worst off. Within the dalit or untouchable category this thesis includes untouchable of both hill and terai. The two highest represented castes and ethnicity categories are higher caste and hill indigenous ethnicity. The himalayan indigenous ethnic group is the smallest. 
Household Demography

The variables under household demography are sex of household head, age of household head, marital status of household head, and the number of productive age or dependent persons in the household. Social factors like sex and marital status are very important. Households headed by men $(81 \%)$ and married household heads $(86 \%)$ are the most common.

The age of household head varies from 14 to 97 years. The households are greatly varied in the number of productive age persons as well as dependent persons. There are households with no productive age person and no dependents. Similarly, the highest number of productive age persons in a household is 17 . Some households have 18 dependent persons.

Region

Geography is one of the crucial factors which affects the life of Nepali people. There are six geographical categories - mountain, urban hill, rural hill, urban terai, rural terai and Kathmandu valley. Rural hill and rural terai are the largest in terms of number of cases.

Dependent Variables 
There are four dependent variables - percent of expenses on food, percent of expenses on health, percent of children currently attending school and quality of housing. On average 41 percent of the expenses is on food and 2 percent is on health. In most of the households children are currently attending school, though there are cases of none of the children in the household attending schools. The quality of housing is measured by the materials used in the roof, wall and floor. It also includes household access to pure drinking water. The value of housing quality ranges from 4 to 16. Most of the households fall near the middle value. 
Table 1: Descriptive Statistics for Independent and Dependent Variables

\begin{tabular}{|c|c|c|c|c|c|}
\hline Variables & No. of Cases & Minimum & Maximum & $\begin{array}{l}\text { Méan/ } \\
\text { Percent }\end{array}$ & $\begin{array}{r}\text { Standard } \\
\text { Deviation }\end{array}$ \\
\hline \multicolumn{6}{|l|}{ Key } \\
\hline Loan from Microfinance $(\log )$ & 3912 & 0 & 2350000 & 17240.85 & \multirow{2}{*}{$\begin{array}{l}67556.32 \\
45119.42\end{array}$} \\
\hline $\begin{array}{l}\text { Amount of Remittance Received } \\
\text { (log) }\end{array}$ & 3912 & 0 & 900000 & 11914.19 & \\
\hline \multicolumn{6}{|l|}{ Socioeconomic Characteristics } \\
\hline Income Less Remittances (log) & 3910 & 0 & 22238400 & 67990.52 & 3.81 \\
\hline HH Head Education (Above SLC) & 277 & 0 & 1 & $7.10 \%$ & .26 \\
\hline HH Head Education (Below SLC) & 3404 & 0 & 1 & $87.00 \%$ & .26 \\
\hline \multicolumn{6}{|c|}{ HH Head with SLC level education is Reference Group. } \\
\hline Total Number of $\mathrm{HH}$ jobs & 3912 & 1 & 52 & 13.13 & 6.85 \\
\hline Higher Caste & 1276 & 0 & 1 & $32.60 \%$ & .47 \\
\hline Himalayan Indigenous & 20 & 0 & 1 & $.50 \%$ & .07 \\
\hline Hill Indigenous & 1257 & 0 & 1 & $32.00 \%$ & 47 \\
\hline Inner Terai Indigenous & 46 & 0 & 1 & $1.20 \%$ & .11 \\
\hline Terai Indigenous & 280 & 0 & 1 & $7.20 \%$ & .26 \\
\hline Madhesis & 467 & 0 & 1 & $11.90 \%$ & .32 \\
\hline \multicolumn{6}{|l|}{ Untouchable is Reference Group. } \\
\hline \multicolumn{6}{|l|}{ Demography Characteristics } \\
\hline Sex of HH Head (1=Male) & 3158 & 0 & 1 & $80.70 \%$ & .39 \\
\hline Age of HH Head & 3912 & 14 & 97 & 45.49 & 14.23 \\
\hline $\begin{array}{l}\text { Marital Status (1=Married, } \\
0=\text { Else) }\end{array}$ & 3345 & 0 & 1 & $85.50 \%$ & .35 \\
\hline \# Productive age persons in $\mathrm{HH}$ & 3912 & 0 & 17 & 3.12 & 1.64 \\
\hline \# Dependent persons in $\mathrm{HH}$ & 3912 & 0 & 18 & 2.39 & 1.78 \\
\hline \multicolumn{6}{|l|}{ Region } \\
\hline Mountain & 384 & 0 & 1 & $9.80 \%$ & .30 \\
\hline Urban Hill & 336 & 0 & 1 & $8.60 \%$ & .28 \\
\hline Rural Hill & 1152 & 0 & 1 & $29.40 \%$ & .46 \\
\hline Urban Terai & 408 & 0 & 1 & $10.40 \%$ & .31 \\
\hline Rural Terai & 1224 & 0 & 1 & $31.30 \%$ & .46 \\
\hline \multicolumn{6}{|l|}{ Kathmandu Valley is Reference Group. } \\
\hline \multicolumn{6}{|l|}{ Dependent Variable } \\
\hline$\%$ of HH Expense on Food & 3912 & 0 & 96 & 40.89 & 20.98 \\
\hline$\%$ of HH Expense on Health & 3912 & 0 & 45 & 1.58 & 4.40 \\
\hline $\begin{array}{l}\% \text { of Children Currently attending } \\
\text { School }\end{array}$ & 2971 & 0 & 100 & 72.45 & 38.45 \\
\hline Housing Quality & 3394 & 4 & 16 & 9.72 & 3.17 \\
\hline
\end{tabular}


Table 2 shows correlations among the four dependent variables - percent of expenses on food, percent of expenses on health, percent of children currently attending school, and quality of housing. The table clearly shows dependent variables are significantly but loosely correlated. The correlations are in both directions. The relation between quality of housing and child education is positive and significant. It indicates that the family which can afford a quality house can also invest in the education of their children. As expected, expenses on food and health are negatively related with quality of housing and child education. Expense on health is a weaker variable than expense on food, which is significantly and negatively related to quality of housing and child education. The relationship between expenses on food and expenses on health is negative but significant. It indicates that the increase in expenses on food is associated with lower expenses on health. Investment in food may bring good health and reduces expenses on health or the poor who have to spend a greater percentage of their income on food have to forego health care. The correlation table also suggests that households with high quality housing and a higher percentage of children attending school spend less in food. Such households must have high income, because financially stronger households do not have to spend as much of their income (relatively) on necessities. 
Table 2: Correlations among Dependent Variables

Correlations

\begin{tabular}{|c|c|c|c|c|}
\hline & $\begin{array}{l}\% \text { of } \mathrm{HH} \\
\text { Expense on } \\
\text { Food }\end{array}$ & $\begin{array}{l}\% \text { of } \mathrm{HH} \\
\text { Expense on } \\
\text { Health }\end{array}$ & $\begin{array}{l}\% \text { of Children between } \\
5 \text { and } 18 \text { Currently } \\
\text { Attending School }\end{array}$ & Quality of House \\
\hline $\begin{array}{l}\% \text { of } \mathrm{HH} \text { Expenses on } \\
\text { Food }\end{array}$ & 1 & & & \\
\hline $\begin{array}{l}\% \text { of HH Expenses on } \\
\text { Health }\end{array}$ & $-.158^{* *}$ & 1 & & \\
\hline $\begin{array}{l}\% \text { of Children } \\
\text { between } 5 \text { and } 18 \\
\text { Currently Attending } \\
\text { School }\end{array}$ & $-.257^{* *}$ & -.023 & 1 & \\
\hline Quality of House & $-.214^{* *}$ & -.005 & $.290^{* * *}$ & 1 \\
\hline
\end{tabular}


The four dependent variables are regressed against twenty-three independent variables to see the strength and direction of the relationships. Loans from microfinance and total remittances received are key independent variables. Other independent variables are socioeconomic characteristics, household demographic characteristics and geography. Household income, education of the household head, household jobs, caste and ethnicity are socioeconomic independent variables. SLC level education of head of household and dalit (untouchable) are reference variables. Demographic characteristics include sex (female $=0$ ), age and marital status of household head (unmarried=0), number of productive age persons and number of dependents in the household. Similarly, region is also an independent variable. Regions include mountain, urban hill, rural hill, urban terai, and rural terai. Kathmandu valley is the reference group.

Four models are used to measure the impact on each of the four livelihood measures. Independent variables are grouped under these four models. 'Model 1' includes key variables only. Similarly, 'Model 2' includes key variables and socioeconomic variables, 'Model 3' includes household demography in addition to the previous two sets and 'Model 4' includes all variables, including region. These four models are in succession and applied to see the influence of these variables and the strength of relationships between key variables and dependent variables.

Table 3 shows relationships between the independent variables and the percent of household expenses on food. The assumption behind this table is that the better the 
household livelihood, the smaller the percentage of expenses on food. The poor household spends a greater percent of their overall expenses on food. The difference of value of $\mathrm{R}^{2}$ in Model 1 and Model 2 is very large. Model 1 can explain only 2.1 percent, but Model 4 can explain 22 percent of the variance in the dependent variable.

Table 3 shows a significant but negative relationship between key independent variables and percent of expenses on food. Larger loans from microfinance and increase in remittances received in households decreases the percent of expense on food. The table clearly shows that the significance of the relationship is persistent with and without holding constant socioeconomic, household demographic, and regional factors.

The education of the household head is significantly related to the percent of expenses on food. The household head with education above SLC spends less on food in comparison to the household head with education below SLC. In all castes and ethnicities, except dalit (untouchable), the relationship is negative and significant. This shows that dalit are the worst off. They spend a greater percentage of expenses on food. Interestingly, contrary to the trend, the relationship of male household head with percent of the expense on food is positive and significant. The household with a male household head spends a greater percentage of their money on food in comparison to the households with a female household head. The geographical regions covered in this research are mountain, urban hill, rural hill, urban terai and rural terai. Kathmandu is the reference variable. Households in all other regions have a higher percentage of expense on food than those in Kathmandu. 
In Table 4 the dependent variable is percent of expenses on health. This table explains the relationship between percent of expenses on health with the same set of independent variables as in the Table 3 . Though the number of cases it includes is fairly high, the highest percent of the dependent variable that the models can explain is only 3.3 percent (Model 4).

Both key variables, loans from microfinance and remittances are positively associated with the percent of expenses on health. Out of these two variables, only loans from microfinance have a significant but weak relationship with the dependent variable throughout all four models.

Among socioeconomic independent variables only total number of jobs in the household has a significant but negative relationship with the percent of expenses on health. The household head with education above SLC has a negative relationship with the dependent variable. Similarly, relative to dalit most of the other castes and ethnicities spend less of their income on food. Amongst all of the household demographic variables, age of the household head and number of dependent persons in the household are positively and significantly related with expenses on health. Similarly, all geographic regions except mountain and rural hill are positively different from the Kathmandu Valley.

Table 4 is not of much importance, but still it can explain the relationship of key independent variables with the percent of expenses on health. Of the two key variables, only microfinance loan are significantly related with health expense. The percent of 
expenses on health is not a strong livelihood indicator in this research. The independent variable chosen here can hardly explain the dependent health variable. There must be other independent variables that are beyond the scope of this research, which can explain the percent of expenses on health properly.

Table 5 focuses on the impact on the education of children whose households are receiving remittances and taking loans from microfinance. It shows the impact on children aged between 5 and 18 who are currently attending schools. The number of cases is 2,971. In Table 5 the highest percentage of variance in the dependent variable is 15.7 percent (Model 4). Across all models, the value of $\mathrm{R}^{2}$ in Table 5 is higher than the value of $\mathrm{R}^{2}$ in Table 4 . This table is very important because it shows positive and significant relationships between remittances received and the percent of children currently attending school. The loans taken from microfinance are also positively related to child education but the relationship is weak.

For this table, caste and education are important socioeconomic predictors. The table clearly shows a negative and significant relationship between education of the household head below SLC and the percent of children currently attending schools. Similarly, this table shows caste and ethnicity, irrespective of household demography and regions, as a very important social factor which can influence the percent of children currently attending school.

Regarding household demography, the most significant household demographic variables are sex of household head, marital status of household head and the number of 
dependent persons in the household. The man as household head is negatively and significantly associated with current child education. If a woman is the household head, the probability of the percent of children currently attending schools is higher. The household with a married household head tends to send a higher percent of their children to school. Similarly, the household with a higher number of dependents tends to send a higher percent of children to school. Geography is an important factor for child education. All geographic regions, except urban hill are significantly and negatively associated with child education, compared to Kathmandu.

Table 6 is about the quality of housing. The total number of cases included in this table is more than 3,000. Model 4 shows the independent variables included here can explain 45 percent of the dependent variable. This is quite interesting.

Out of the two key variables, only loans taken from microfinance are significantly and negatively associated with the quality of housing. Households which have microfinance loans have lower quality of housing. It may indicate that poor people are more associated with microfinance. This table shows a very weak relationship between remittances received and quality of housing.

The education of the household head, the total number of household jobs and the caste and ethnicity are important socioeconomic variables in this table. The education level of the household head below SLC is significantly and negatively associated with quality of housing. Household heads with education below SLC tend to have lower quality housing. Similarly, households with more jobs have poor quality housing. It 
shows the poorer household tends to have a large number of jobs. All castes and ethnic groups compared to Dalit have higher housing quality. High caste, hill and Terai indigenous ethnic groups are significantly associated with the quality of housing. In terms of household demographic variables, sex of the household head, marital status of the household head and number of dependent persons in the household are significantly associated with quality of housing. Households with men as their "head", have higher quality housing. Similarly, the married household head and households with a large number of dependents have better quality housing. Out of all geographic variables, housing only in urban terai is not significantly different than Kathmandu, all others have lower quality housing. Model 4 of this table shows that region is a stronger variable than microfinance in predicting quality of housing because the coefficient for microfinance becomes less significant.

\section{Summary and Conclusion}

The research shows that there is clear impact of microfinance and remittances on the livelihoods of Nepali people. Out of four livelihood variables, microfinance is significantly associated with food, health, and housing. Microfinance loans is negatively associated with percent of expenses on food and quality of housing (i.e., necessities), but positively associated with the percent of expenses on health. It indicates that if money increases in the household the percent of expenses on food decreases. The household which takes more loans from microfinance has poor quality housing. It also means that 
poor people are more involved in microfinance. The positive significant relationship of microfinance with percent of expenses on health shows that people might take more loans if they face health problems in their household.

Similarly, the size of remittances is significantly associated with two livelihood variables - food and education, but in an opposite direction. It has a negative association with food and a positive association with child education. Remittances bring additional money to the household. Whenever a household increases money the percent of expenses on food decreases. The significant association of remittances with percent of children currently attending school shows that improvement in the financial situation of a household has a positive impact on the education of children.

Out of all independent variables, the total number of jobs in the household is the only variable which is significantly and negatively associated with all four livelihood variables. Interestingly, household income is the weakest independent variable. It is significantly and negatively related with food only. Income has no significant relationship with health, education and housing. The income is overshadowed by other stronger factors like the education level of household head, caste and ethnicity, sex of household head, marital status of household head and the number of dependent persons in the household. These variables are significantly associated with food, education and housing. It may indicate that Nepal is still a traditional country, where social factors are stronger than economic factors. 
Age of household head, number of productive age persons in the house and geographic regions are also significantly related to some of the livelihood variables, especially food and housing. These variables are stronger than income but not as influential as the above mentioned variables.

The NLSS II survey could not enumerate households from the far western development region in Nepal because of existing conflict. The data set does not represent the far west, which is the most remote and the most under-developed region. I would like to see the impact of microfinance and remittances on the livelihood of people in this region.

This research shows some interesting relationships between key and dependent variables. Microfinance has no significant relationship with child education. Similarly, remittances are not significantly correlated with expenses on health and quality of housing. I think future research should cover these issues. I believe such research will uncover some valid and vibrant reasons behind these relationships. It might be specific to Nepal or might open some new horizon in this field.

Most fascinatingly, household income is not significantly related with education, health and housing quality. I would like to see future research focus on the relationship between income and education, health, and housing quality. I believe such research will bring some ground realities about these issues. 
Table 3: Dependent Variable is Percent of Expenses on Food

\begin{tabular}{|c|c|c|c|c|}
\hline Variables & Model 1 & Model 2 & Model 3 & Model 4 \\
\hline \multicolumn{5}{|l|}{ Key } \\
\hline Loan from MF $(\log )$ & $-.39 * * *$ & $-.22 * *$ & $-.27 * * *$ & $-.32 * * *$ \\
\hline Amount of Remittances & $-.53 * * *$ & $-.60 * * *$ & $-.45 * * *$ & $-.48 * * *$ \\
\hline \multicolumn{5}{|l|}{ Received (log) } \\
\hline \multicolumn{5}{|l|}{ Socioeconomic Characteristics } \\
\hline Income Less Remittances (log) & & $-1.12 * * *$ & $-1.01 * * *$ & $-1.03 * * *$ \\
\hline HH Head Education (Above & & $-3.89 *$ & $-3.67 *$ & -2.68 \\
\hline \multicolumn{5}{|l|}{ SLC) } \\
\hline HH Head Education (Below & & $9.32 * * *$ & $9.45^{* * *}$ & $8.85 * * *$ \\
\hline \multicolumn{5}{|c|}{ SLC) } \\
\hline \multicolumn{5}{|c|}{ HH Head with SLC level Education is the reference Group. } \\
\hline Total Number of $\mathrm{HH}$ jobs & & $-.55 * * *$ & $-.40 * * *$ & $-.59 * * *$ \\
\hline Higher Caste & & $-15.80^{* * *}$ & $-15.37 * * *$ & $-16.31 * * *$ \\
\hline Himalayan Indigenous & & -6.78 & -6.72 & -7.39 \\
\hline Hill Indigenous & & $-7.38 * * *$ & $-6.51 * * *$ & $-7.02 * * *$ \\
\hline Inner Terai Indigenous & & -.06 & -.07 & .23 \\
\hline Terai Indigenous & & $-11.64 * * *$ & $-11.32 * * *$ & $-9.62 * * *$ \\
\hline Madhesis & & $-8.39 * * *$ & $-7.64 * * *$ & $-6.54 * * *$ \\
\hline \multicolumn{5}{|c|}{ Untouchable is the reference caste variable. } \\
\hline \multicolumn{5}{|l|}{ Demographic Characteristics } \\
\hline Sex of HH Head (1=Male) & & & $3.60 * * *$ & $3.55 * * *$ \\
\hline Age of $\mathrm{HH}$ Head & & & $-.12 * * *$ & $-.13 * * *$ \\
\hline $\begin{array}{l}\text { Marital Status (1=Married, } \\
0=\text { Else) }\end{array}$ & & & $-2.19^{*}$ & -1.90 \\
\hline \# Productive age persons in $\mathrm{HH}$ & & & $-1.49 * * *$ & $-.95^{* * *}$ \\
\hline \# Dependent persons in $\mathrm{HH}$ & & & .33 & $.49^{*}$ \\
\hline \multicolumn{5}{|l|}{ Region } \\
\hline Mountain & & & & $7.77 * * *$ \\
\hline Urban Hill & & & & $3.55^{*}$ \\
\hline Rural Hill & & & & $7.51 * * *$ \\
\hline Urban Terai & & & & $3.91 * *$ \\
\hline Rural Terai & & & & 2.42 \\
\hline \multicolumn{5}{|l|}{ Kathmandu is Reference Group. } \\
\hline $\mathrm{R}^{2}$ & .021 & .187 & .209 & .220 \\
\hline No. of Cases & 3912.00 & 3912.00 & 3912.00 & 3912.00 \\
\hline
\end{tabular}


Table 4: Dependent Variable is Percent of Expense on Health

\begin{tabular}{|c|c|c|c|c|}
\hline Variables & Model 1 & Model 2 & Model 3 & Model 4 \\
\hline \multicolumn{5}{|l|}{ Key } \\
\hline Loan from Microfinance (log) & $.04 * *$ & $.04 * *$ & $.05^{* * *}$ & $.05^{* * *}$ \\
\hline Amount of Remittances & .02 & .02 & .03 & .02 \\
\hline \multicolumn{5}{|l|}{ Received (log) } \\
\hline \multicolumn{5}{|l|}{ Socioeconomic Characteristics } \\
\hline Income Less Remittances (log) & & $.08^{*}$ & .05 & .04 \\
\hline \multirow{2}{*}{\multicolumn{5}{|c|}{ SLC) }} \\
\hline & & & & \\
\hline HH Head Education (Below & & .42 & .37 & .34 \\
\hline \multirow{2}{*}{\multicolumn{5}{|c|}{$\begin{array}{l}\text { SLC) } \\
\text { HH Head with SLC level education is Reference Group. }\end{array}$}} \\
\hline & & & & \\
\hline Total Number of HH jobs & & $-.04 * * *$ & $-.08 * * *$ & $-.08 * * *$ \\
\hline Higher Caste & & .01 & .003 & .21 \\
\hline Himalayan Indigenous & & -1.09 & -1.19 & -.69 \\
\hline Hill Indigenous & & -.37 & $-.48^{*}$ & -.24 \\
\hline Inner Terai Indigenous & & -.84 & -.87 & -.88 \\
\hline Terai Indigenous & & -.08 & -.08 & -.34 \\
\hline Madhesis & & .10 & -.14 & -.34 \\
\hline \multicolumn{5}{|l|}{ Untouchable is Reference Group. } \\
\hline \multicolumn{5}{|l|}{ Demographic Characteristics } \\
\hline Sex of HH Head (1=Male) & & & .39 & .40 \\
\hline Age of HH Head & & & $.04 * * *$ & $.04 * * *$ \\
\hline \multirow{2}{*}{\multicolumn{5}{|c|}{$(1=$ Married, $0=$ Else $)$}} \\
\hline & & & .06 & .04 \\
\hline \# Dependent persons in HH & & & $.13^{* *}$ & $.12^{*}$ \\
\hline \multicolumn{5}{|l|}{ Region } \\
\hline Mountain & & & & -.26 \\
\hline Urban Hill & & & & .34 \\
\hline Rural Hill & & & & .23 \\
\hline Urban Terai & & & & .50 \\
\hline Rural Terai & & & & $.79 *$ \\
\hline \multicolumn{5}{|l|}{ Kathmandu Reference Group. } \\
\hline $\mathrm{R}^{2}$ & .002 & .009 & .029 & .033 \\
\hline No. of Cases & 1200 & 0.00 & & \\
\hline
\end{tabular}

* $\mathrm{P}<.05,{ }^{*} * \mathrm{P}<.01$ and $* * * \mathrm{P}<.001$ (Two-tailed), Significant difference between groups 
Table 5: Dependent Variable is Percent of Children 5-18 Currently Attending School

\begin{tabular}{|c|c|c|c|c|}
\hline Variables & Model 1 & Model 2 & Model 3 & Model 4 \\
\hline \multicolumn{5}{|l|}{ Key } \\
\hline Loan from Microfinance $(\log )$ & .12 & .07 & .11 & .27 \\
\hline Amount of Remittances & $.52 * *$ & $.52 * *$ & $.36^{*}$ & $.47 * *$ \\
\hline \multicolumn{5}{|l|}{ Received (log) } \\
\hline \multicolumn{5}{|l|}{ Socioeconomic Characteristics } \\
\hline Income Less Remittances (log) & & .46 & .50 & $.73 *$ \\
\hline HH Head Education (Above & & -1.06 & .09 & -3.18 \\
\hline SLC) & . & & & \\
\hline HH Head Education (Below & & $-14.36 * * *$ & $-13.97 * * *$ & $-11.30 * * *$ \\
\hline \multicolumn{5}{|l|}{ SLC) } \\
\hline \multicolumn{5}{|c|}{ HH Head with SLC level education is Reference Group. } \\
\hline Total Number of HH jobs & & $-.61 * * *$ & $-.85 * * *$ & $-.37 *$ \\
\hline Higher Caste & & $26.03 * * *$ & $26.38 * * *$ & $26.01 * * *$ \\
\hline Himalayan Indigenous & & 21.28 & $23.16^{*}$ & 21.94 \\
\hline Hill Indigenous & & $18.42 * * *$ & $18.80 * * *$ & $16.66^{* * *}$ \\
\hline Inner Terai Indigenous & & 10.54 & 10.94 & 7.83 \\
\hline Terai Indigenous & & $10.34 * *$ & $10.12 * *$ & $9.69 * *$ \\
\hline Madhesis & & 1.45 & .14 & .18 \\
\hline \multicolumn{5}{|l|}{ Untouchable is Reference Group. } \\
\hline \multicolumn{5}{|l|}{ Demography Characteristics } \\
\hline Sex of HH Head (1=Male) & & & $-6.86^{* *}$ & $-5.94 * *$ \\
\hline Age of $\mathrm{HH}$ Head & & & .09 & .10 \\
\hline Marital Status ( $1=$ Married, & & & $14.85^{* * * *}$ & $14.09 * * *$ \\
\hline \multicolumn{5}{|l|}{$0=$ Else) } \\
\hline \# Productive age persons in $\mathrm{HH}$ & & & .05 & $-1.22 *$ \\
\hline \# Dependent persons in $\mathrm{HH}$ & & & $1.77 * * *$ & $1.54 * *$ \\
\hline \multicolumn{5}{|l|}{ Region } \\
\hline Mountain & & & & $-23.80 * * *$ \\
\hline Urban Hill & & & & -6.01 \\
\hline Rural Hill & & & & $-18.59 * * *$ \\
\hline Urban Terai & & & & $-8.60 * *$ \\
\hline Rural Terai & & & & $-17.02 * * *$ \\
\hline \multicolumn{5}{|c|}{ Kathmandu Valley is Reference Group. } \\
\hline $\mathrm{R}^{2}$ & .004 & .113 & .131 & .152 \\
\hline No. of Cases & 2971.00 & 2971.00 & 2971.00 & 2971.00 \\
\hline
\end{tabular}

$* \mathrm{P}<.05,{ }^{*} \mathrm{P}<.01$ and $* * * \mathrm{P}<.001$ (Two-tailed), Significant difference between groups 
Table 6: Dependent Variable is Quality of Housing

\begin{tabular}{|c|c|c|c|c|}
\hline Variables & Model 1 & Model 2 & Model 3 & Model 4 \\
\hline \multicolumn{5}{|l|}{ Key } \\
\hline Loan from Microfinance (log) & $-.09 * * *$ & $-.05 * * *$ & $-.03 * *$ & -.001 \\
\hline Amount of Remittances & -.003 & .002 & -.01 & .01 \\
\hline \multicolumn{5}{|l|}{ Received (log) } \\
\hline \multicolumn{5}{|l|}{ Socioeconomic Characteristics } \\
\hline Income Less Remittances (log) & & .03 & -.04 & -.01 \\
\hline HH Head Education (Above & & $1.65^{* * *}$ & $1.58^{* * *}$ & $1.02 * * *$ \\
\hline \multicolumn{5}{|l|}{ SLC) } \\
\hline HH Head Education (Below & & $-1.83 * * *$ & $-1.53^{* * * *}$ & $-1.02 * * *$ \\
\hline \multicolumn{5}{|l|}{ SLC) } \\
\hline \multicolumn{5}{|c|}{ HH Head with SLC level education is Reference Group. } \\
\hline Total Number of HH jobs & & $-.13 * * *$ & $-.23 * * *$ & $-.10 * * *$ \\
\hline Higher Caste & & $1.26 * * *$ & $1.34 * * *$ & $1.28 * * *$ \\
\hline Himalayan Indigenous & & $2.53 * * *$ & $2.77 * * *$ & $2.65 * * *$ \\
\hline Hill Indigenous & & $1.15^{* * * *}$ & $1.15^{* * * *}$ & $.88 * * *$ \\
\hline Inner Terai Indigenous & & .35 & .50 & .27 \\
\hline Terai Indigenous & & $.58^{*}$ & .32 & .07 \\
\hline Madhesis & & $1.50^{* * * *}$ & $1.09 * * *$ & $.82 * * *$ \\
\hline \multicolumn{5}{|l|}{ Untouchable is Reference Group. } \\
\hline \multicolumn{5}{|l|}{ Demographic Characteristics } \\
\hline Sex of HH Head (1=Male) & & & $.28^{*}$ & $.25^{*}$ \\
\hline Age of $\mathrm{HH}$ Head & & & .001 & .01 \\
\hline $\begin{array}{l}\text { Marital Status (1=Married, } \\
0=\text { Else) }\end{array}$ & & & $.69 * * *$ & $.54 * * *$ \\
\hline \# Productive age persons in $\mathrm{HH}$ & & & $.51 * * *$ & $.18^{* * *}$ \\
\hline \# Dependent persons in $\mathrm{HH}$ & & & $.14 * * *$ & $.07^{*}$ \\
\hline \multicolumn{5}{|l|}{ Region } \\
\hline Mountain & & & & $-3.67 * * *$ \\
\hline Urban Hill & & & & $-.78 * * *$ \\
\hline Rural Hill & & & & $-3.58^{* * * *}$ \\
\hline Urban Terai & & & & -.26 \\
\hline Rural Terai & & & & $-2.58 * * *$ \\
\hline \multicolumn{5}{|l|}{ Kathmandu is Reference Group. } \\
\hline $\mathrm{R}^{2}$ & .021 & .270 & .322 & .450 \\
\hline No. of Cases & 3394.00 & 3392.00 & 3392.00 & 3392.00 \\
\hline
\end{tabular}

${ }^{*} \mathrm{P}<.05,{ }^{*} * \mathrm{P}<.01$ and $* * * \mathrm{P}<.001$ (Two-tailed), Significant difference between groups 


\section{CHAPTER II}

\section{Review of Literature}

One of the common features of microfinance and migration is that both function on the basis of social capital, such as networks, trust, and relationships among people. Microfinance uses social capital as the collateral for a loan. People out-migrate and remittances are shared using their networks. Both microfinance and migration have the same objective (i.e. to bring money into the household). There are some gender-based differences as well. Migration and remittances are dominated by men, and microfinance is dominated by women. Microfinance and migration are helpful for poor households. Hence, both men and women of poor households try to increase their income through different livelihood strategies. Many men generate money from outside sources through migration, while women tend to generate money within the community through microfinance.

\section{Microfinance}

Nepal's government is using microfinance as a tool for poverty alleviation. Some of the important government programs which use microfinance are the Intensive Banking Program (IBP), Small Farmers Development Programs (SFDP), Production Credit for Rural Women (PCRW), Micro Credit Project for Women (MCPW), and Grameen Bank. In addition, there are several savings credit organizations, cooperatives and NGOs, all of 
which are working with the poor through microfinance. Microfinance programs supported by international or local Non-Government Organizations (I/NGOs) are more effective than government-run programs (Ledgerwood 1997). With the exception of Grameen Bikas Bank, all other microfinance programs run by the government are unsustainable. The only sustainable Micro Finance Organizations (MFOs) are indigenous, which get no outsider support, but such organizations have very limited outreach.

In Nepal, MFOs suffer from a number of problems. The major problems are poor management and limited outreach (Ledgerwood 1997). Difficult geographical regions are a barrier for delivering microfinance services (Bhatta 2001), which severely affect the outreach of such organizations. Other identified problems are a lack of coordination with district government agencies, poor repayment, and the high cost of service delivery (Takahatake and Maharjan 2002). To solve such problems, Ledgerwood (1997) recommends the skill development of professionals who are involved in the microfinance sector. She also suggests that the Nepal government should be engaged in wholesale lending rather than retailing programs. In wholesale lending, the Nepal government would lend money to different Micro Finance Organizations which then would be responsible to lend money to citizens.

There are two approaches to microfinance - the social service approach and business approach (Ledgerwood 1997; Takahatake and Maharjan 2002; Rankin 2001). 
The social service approach, also called the "social banking approach," the "state led approach" or the "Welfarists approach," mainly focuses on the social well-being of the community and less on economic development. The business approach, also called the "client-focused approach," or the "market-led approach" or the "institutionalist's approach" gives priority to economic development and banking sustainability. The main difference between these two is the emphasis of one over the other. The social approach is supply driven and the business approach is demand driven.

There is a disagreement among scholars about which approach is better. Hulme and Mosely (1996) are on the side of the social banking approach. They think this approach better serves the poor. For them, the business approach excludes the poor in order for the bank to be sustainable. The business approach is the concept of capitalism, which is based on the principle of free markets and less government involvement. Gargan (1996) described the business approach as "grassroots capitalism." Microfinance helped capitalism to spread in a grassroots manner around the world. Ledgerwood (1997) thinks that the business approach is necessary for effective and sustainable services. Both arguments make valid points. However, for the best result, both inclusion of the poor and banking sustainability is necessary. Takahatake and Maharjan (2002) argue that the solution is in the close coordination between government welfare programs (training, social service, literacy program, and health program) and the business approach of microfinance. The coordination would allow resource sharing between microfinance and 
the government welfare programs, which could reduce the cost of microfinance. In this way, microfinance could be sustainable and the poor would benefit with different social programs without any cost burden to the microfinance institutions. This situation would create an environment for providing long-term microfinance services to the poor.

This discussion is related to the discussion about the difference between 'microfinance' and 'microcredit.' These terminologies are very close but maintain some differences. Microfinance is a development approach which provides financial services (i.e., savings, credit and insurance) as well as social services (i.e., empowerment, advocacy, training, and solidarity) (Qudrat and Rahman 2006; Ledgerwood 1999; Robinson 2002). Microfinance helps the poor by building social solidarity, providing loans, increasing transparency within groups, and providing a feeling of psychological empowerment. On the other hand, microcredit is the loan delivery and recovery program (Gutberlet 2007) that aims to support the poor through providing small loans for their economic betterment.

Women are the main target group of microfinance (Rankin 2001; Stoesz et al 1999; Fisher and Sriram 2002), which provides working capital to start-up businesses and helps people become self-employed (Versluysen 1999). Microfinance helps poor families to survive by providing loans for women to establish small enterprises. Women are energetic, productive, and contribute more income for the social well-being of family 
members than men. Women are more responsible and pay loans back (Rankin 2001). Hence, the microfinance sector encourages and targets women as its client.

Another valid reason for the higher priority of women in microfinance is related to their role in household budget management. In most of the households, women are responsible for managing money or the household budget (Rogaly, Castillo, and Serrano 2004). Generally, the male household head hands over some portion of his earned money to his wife. Then after, the wife spends money wisely on education, food, health care, or as per household needs.

The households, which participate in microfinance, experience positive impacts on the lives of their members (Hulme and Mosley 1996; Simanowitz and Walter 2002; Midgley 2008; Chemin 2008). Such households increase their income, diversify income sources, increase savings, raise asset accumulation, and spend more in food, education and health care. They can better cope times of food scarcity or health emergencies. There are two reasons such households spend more in education and health: first, they have more money to spend and second, they have increased awareness of the importance of education and health care (Sankar 2005).

The household impact of microfinance from a gender perspective is also studied. The household impact of loans taken by women has a stronger effect than the impact of loans taken by men (Sengupta and Aubuchon 2008). The households with loans taken by women have better health care and child nutrition and better levels of childhood 
education (Smith 2002; Khandker 2005). Chemin (2008) shows very interesting gender differences. According to him, generally the amount of loans taken by the men are bigger than the amount of loans taken by women. It clearly shows that despite of the higher amount of loan taken by men, its household impact is less.

Microfinance also helps women to have more control over household income and assets (Rogaly, Castillo, and Serrano 2004). However, women in women-headed households have greater control over income and assets than the women in male-headed households (Padia 2005).

The purposes of the loans taken from microfinance are different. Loans taken are used for personal or business reasons (Padia 2005; Parthasarathy 2005). Loans are taken for medical treatment, for education related expenses, for transportation (e.g., bicycles), for durable goods (e.g., televisions and radios). Loans are used for maintaining the house, as well as for religious purposes. With loans from microfinance they open small shops, spend money in agricultural inputs (e.g., seeds and fertilizers), buy livestock (e.g., goats, poultry and cows), or establish small businesses like flower selling, rope making, grocery shops, and bangle selling.

The literature related to microfinance shows that there is a general agreement among researchers and professionals that access to microfinance reduces vulnerability of the households (i.e., households are stopped from falling further into poverty) (Develtere and Huybrechts 2005). 
Though there is much literature about the contributions and success stories of microfinance, it is not free from malpractice. Shakya and Rankin (2008) identified a number of unethical or illegal behaviors that microfinance clients are secretly engaged in. The most common malpractice is misuse of funds in an unproductive sector. Clients take money in the name of enterprises and misuse it for food, parties, and other cultural practices. Another form of malpractice is multiple borrowing in which clients take loans from a number of places and pay one with the other. When one group member cannot pay his/her loan, his/her group members may apply pressure to sell his/her home stuff to pay the loan back so that other members in the group receive access to loan funds.

Despite such malpractice, microfinance has proven to be an effective tool for poverty alleviation. Large numbers of NGOs are engaged in this sector. However, the effort of NGOs can help some communities but not the entire nation. Nationwide sustainable microfinance service can be achieved only through a supportive national policy environment, market infrastructure, a long term plan, trained human resources, and suitable microfinance legislation (Douglas and Buss 2001; FAO 2005).

\section{Remittance}

In the 2005-2006 fiscal year, the amount of remittance flow exceeded \$200 billion (Coss 2006; Ratha 2007). South Asia alone has been receiving around $\$ 50$ billion every year (Seddon 2004). India is the largest recipient in south Asia and in the world. A large 
number of the Nepali population are engaged in migration and Nepal is getting a large amount of money in remittances. The Nepal Living Standard Survey (2003/04) shows that 32 percent of households received remittances, and the amount of remittance was NRs 46,365,466,726 (CBS 2004). In 2004, the share of remittances was 11.7 percent of the total GDP of Nepal (World Bank 2006). Despite the large number of people involved in the migration and the large amount of money entering as remittances, Nepali planners, researchers and policy makers put a low priority on this sector (Seddon et al 2002). There are not many studies or much research on remittances and migration.

The direction of the flow of remittances is the opposite of the direction of migration (Coss 2006; Seddon 2004). Most remittances flow from high developed to low developed countries, and from cities to rural areas. However, the flow of migration is from the low developed to the high developed countries and from the rural areas to the cities within the country.

There are two ways to send remittances; they are formal and informal (Coss 2006; Ratha 2007; Seddon 2004; Seddon et al 2002). The above mentioned remittance figure is adopted from a formal source. Scholars who are engaged in the study of remittances believe that a huge amount of the remittance flows through informal sources transactions between persons. No one knows the exact amount of money flowing through informal sources. There would be no record of such transactions with the government. It is totally person to person approach. All transactions are done secretly, without informing 
government financial institutions. Hundi is an example of an informal source. A person gives money to the person who runs the Hundi and who is responsible for delivering the money in the recipient country. Neithers governments benefits from this transaction.

There are two main reasons behind the existence of informal sources (Coss 2006). First, informal sources are a cheap mechanism to send money. Second, the formal source cannot operate in remote areas. According to Seddon (2004), the status of migrants also influences the remittance behavior. Most of the legal migrants send money through the formal institutions. Illegal migrants have no choice except the informal means. Hence, Seddon (2004) argues, it is necessary to develop an easier formal process to send money. An easy process helps to create transparency. Since microfinance institutions are working in remote areas, Coss (2006) thinks that a partnership with microfinance institutions can help to send remittances formally in the remote areas.

Migration has been in practice for centuries in South Asia, including Nepal (McDowell and Haan 1997; Seddon et al 2002; Gill 2003; McDowell and Haan 1997). In Nepal, people have been migrating within the country and outside of the country. While there is some movement in the opposite direction, most people migrate from rural to urban areas, from the hill to the plain areas, from the west to the east, and from the north to the south part of the country (Seddon et al 2002; Seddon 2004; Gill 2003). India is the favorite and the most accessible country for international migration. Recently, migration 
to the Persian Gulf countries, Malaysia, South Korea, Japan, Europe, Australia and America is increasing.

There are two factors (pushing and pulling) behind the migration (Gill 2003; Seddon et al 2002). The pushing factors are poverty, food insecurity, and conflict; the pulling factor is seasonal opportunity to work for a higher income. Though most of the population of Nepal are farmers, the farming alone cannot produce enough household inkind and cash income to survive (Seddon 2004). This situation compels people to think over an alternate source of income. Hence, migration is a rational choice to maximize the advantage (McDowell and Haan 1997). In Nepal, for both the higher and the lower caste, migration is one of the best sources of income, using their spare time out of the farming. For the lower caste, the existing caste based inequality is the additional factor for choosing migration (McDowell and Haan 1997). After migrating outside of their society, the untouchables get the economic advantage, but can also live in a discrimination free environment. For the higher castes, which have a relatively better economic situation than the lower caste, migration is a good means by which they can break the poverty cycle (Gill 2003). However, the irony is that migration does not help the very poor families (Seddon et al 2002). They cannot risk even a small loan for out-migration, or others will not think they are credit worthy.

Another dimension to migration in Nepal is length of time (Seddon et al 2002; Gill 2003). Short term is seasonal migration, which starts right after the planting of rice 
paddies and exists for four months. All the people who migrated return for the paddy harvest. Generally, men are involved in such migration, and women stay home and take care of the chores related to farming such as weeding, irrigating, and putting in fertilizers (Seddon et al 2002). Short term seasonal migration is an every year phenomenon. Long term migration lasts for more than four months, and it is not a yearly activity. Certain ethnic groups in Nepal such as Gurung, Rai, Limbu go for military recruitment in India and the UK and serve there for years. Now, people from the other ethnic groups also go for longer periods as laborers in Malaysia, South Korea, and the Persian Gulf countries.

The households get money from remittances in both forms, cash and in-kind. Both forms of financial incentives are significant for households (Brown 1994). It is interesting to know that the economic situation of migrants' households in the home country also affects the amount of remittances migrants send back to their home country. Migrants who are from poorer households send more money back home than migrants who are from rich households (Osili 2007). Similarly, households in less developed regions are mostly dependent on remittances than the households in developed region (Koc and Onan 2004).

The remittances which migrants sent from outside of their community have a very positive impact on the household and the community (Coss 2006; Ratha 2007; Seddon 2004). According to Acosta, Fajnzylber and Lopez (2008), who have done studies in 11 Latin American countries, the household impact of remittances is different for different 
countries and different socioeconomic groups. The study shows that the saving rate increases in poorer households, but decreases as households get richer. The households in the higher bracket of income spend more money in education of households' members. Even in households with low income, children experience an increase in educational attainment. In case of health care, the remittances improve children's health even in poor households. But remittances have a negative relationship with labor supply within households.

According to the International Organization for Migration (2006), remittances have positive household impacts. The money received as remittances increases household saving (Zarate-Hoyos 2004). Such savings are very useful to meet basic needs as well as very helpful at the time of emergency, and in service of elderly people.

Households use the money received from remittances for different purposes including food and clothing, medicine, purchase of land, home construction and repair, repaying loans, marriage and ceremonies, education, telecommunication, savings, funding other people's migration, or investment in business and health care (ZarateHoyos 2004; Koc and Onan 2004; IOM 2005; Bobeva 2005; Deneulin 2006).

Remittances have a positive impact on household welfare (Koc and Onan 2004). Households which received remittances are better off than the households which do not. Comparatively, the households which receive money from remittances spend more money on food, durable goods, health, and housing than the households which do not 
receive money from remittances (Koc and Onan 2004; Adams, Richard H., Jr. 2006; Airola 2007). Such households spend more money on local enterprises activities. They buy more local goods and invest money to open and run businesses. Such investment generates more demand on the local level, which ultimately produces more local business as well as employment opportunities for people who do not migrate (Bobeva 2005;

Adams, Richard H., Jr. 2006).

According to Ratha (2007), the positive impact of remittances is possible only if the policy implementation is effective. Effective policies can only encourage people to use remittances in a productive manner. If people do not have a suitable environment for investment, most of the money is spent in consumption and people become dependent on the remittances. People's main goal can become to go out of the country. Those who live in the country also keep expecting money from the outside. They become lazy and avoid labor, which results in less input in local production. Hence, some scholars think outmigration is harmful to development (McDowell and Haan 1997). 


\section{REFERENCES}

Acosta, Pablo, Pablo Fajzylber and J. Humberto Lopez. 2008. "Remittances and Household Behavior: Evidence for Latin America." Pp. 133-169 in Remittances and Development: Lesson from Latin America, edited by Pablo Fajnzylber and J. Humberto Lopez. Washington DC: The World Bank.

Adams, Richard H., Jr. 2006. "International Remittances and the Household: Analysis and Review of Global Evidence.” Journal of African Economies 15(2): 396-425.

Airola, Jim. 2007. "The Use of Remittance Income in Mexico." IMR 41(4): 850-859.

Bhatta, Gambhir. 2001. "Small Is Indeed Beautiful but... The Context of Microcredit Strategies in Nepal," Policy Studies Journal 29 (2): 283-295.

Bobeva, Daniela. 2005. “Turning Remittances into Investments.” Migration, Remittances and Development. Paris: OECD.

Blumberg, Rae Lesser. 1989. "Making the Case for the Gender Variable: Women and the Wealth and Well-being of Nations." Technical Reports on Gender and Development, No. 1, Washington DC: Women in Development Office, USAID.

Brown, Richard P.C. 1994. "Migrants' Remittances, Savings and Investment in the South Pacific.” International Labor Review 133(3): 347-367.

Central Bureau of Statistics. 2004. Nepal Living Standard Survey 2003/04. Kathmandu: Department of Printing.

Chambers, R. and G. Conway. 1992. "Sustainable Rural Livelihoods: Practical Concept for the $21^{\text {st }}$ Century." IDS Discussion Paper 296. Bringhton: IDS.

Chemin, Matthieu. 2008. "The Benefits and Costs of Microfinance: Evidence from Bangladesh." Journal of Development Studies 44(4): 463-484.

Coss, Raul Hernandez. 2006. The Impact of Remittances: Observations in Remitting and Receiving Countries: Discussion Paper prepared for the G24 XXIII Technical 
Group Meeting Singapore, September 13-14, 2006. Intergovernmental Group of Twenty Four.

Develtere, Patrick and An Huybrechts. 2005. "The Impact of Microcredit on the Poor in Bangladesh.” Alternatives 30: 165-189.

Deneulin, Severine. 2006. "Individual Well-being, Migration Remittances and the Common Good." The European Journal of Development Research 18(1): 45-58.

Dhakal, Tek Nath. 2006. NGOs in Livelihoods Developments: Nepalese Experience. New Delhi: Adroit Publishers.

Douglas, R. Snow and Terry, F. Buss. 2001. "Development and the Role of Microcredit." Policy Studies Journal 29 (2): 296-307.

Fisher, Thomas and M.S. Sriram. 2002. Beyond Micro-Credit: Putting Development back into Micro-Finance. New Delhi: Vistaar Publications.

Food and Agriculture Organization. 2005. Microfinance and Forest-based Small-scale Enterprises: FAO Forestry Paper 146. Rome.

Frost, Stephen. 2006. "Building Hong Kong: Nepalese Labor in the Construction Sector." Pp. 110-125 in Transnational Migration and Work in Asia, edited by K.

Hewinson and K. Young. London and New York: Routledge. Taylor and Francis Group.

Gargan, Edward. 1996. “People's Banks' Help Rescue Poor Indonesians,” New York Times (February 28).

Gill, Gerard. 2003. Seasonal Labour Migration in Rural Nepal: A Preliminary Overview. Working Paper 218. Overseas Development Institute. London. UK. Retrieved on February 04, 2009 (http:/www.odi.org.uk/Livelihoodoptions/papers/wp218.pdf)

Gutberlet, Jutta. 2007. Micro-credit and recycling co-ops: grassroots initiatives to alleviate poverty. Paper presented at the International CIRIEC Research Conference on the Social Economy. Victoria, Canada. Retrieved Feb 122009 (http://conference.se-es.ca/wp-content/uploads/2008/02/jutta-gutberlet-re.pdf). 
Harris, Sam Daley. 2009. State of the Microcredit Summit Campaign Report 2009. Washington DC: The Microcredit Summit Campaign. Retrieved December 2, 2009 (http://www.microcreditsummit.org/uploads/socrs/SOCR2009_English.pdf).

Hulme, David and Pul Mosely. 1996. Finance Against Poverty. Vols. 1 and 2. London: Routledge.

International Organization for Migration. 2005. Dynamics of Remittance Utilization in Bangladesh. IOM Migration Research Series No. 18. Geneva: International Organization for Migration.

-----. 2006. Migration for Development: Within and Beyond Frontiers. Geneva: International Organization for Migration.

Khandker, Shahidur. 2005. "Microfinance and Poverty: Evidence Using Panel Data from Bangladesh." World Bank Economic Review 19(2): 263-86.

Koc, Isrnet and Isil Onan. 2004. "International Migants' Remittances and Welfare Status of the Left-Behind Families in Turkey." International Migrants' Remittances 38(1): 78-112.

Midgley, James. 2008. "Microenterprise, global poverty and social development." International Social Work 51(4): 467-479.

Ledgerwood, Joanna. 1997. "Critical Issues in Nepal's Micro Finance Circumstances." Iris. Retrieved January 29, 2009

(http://www.iris.umd.edu/download.aspx?ID=4ca01af2-72b4-479c-85e6-a189348490d8).

-----. 1999. Sustainable Banking with the Poor: Microfinance Handbook-An Institutional and Financial Perspective. Washington DC: The World Bank.

McDowell, Christopher and Arjan de Haan. 1997. Migration and Sustainable livelihoods: A Critical Review of the Literature. Working paper number 65. University of Sussex UK: Institute of Development Studies.

Osili, Una Okonkwo. 2007. "Remittances and savings from international migration: Theory and evidence using a matched sample." Journal of Development Economics 83 (2): 446-465. 
Padia, Veena. 2005. "Social Mobilization and Micro-credit for Women's Empowerment: A Study of the DHAN Foundation." Pp. 161-199 in Micro-Credit, Poverty and Empowerment: Linking the Triad, edited by Neera Burra, Joy DeshmukhRanadive and Ranjani K. Murthy. New Delhi, Thousand Oaks, London: SAGE Publications and UNDP.

Parthasarathy, Soma Kishore. 2005. "Awareness, Access, Agency: Experiences of Swayam Shikshan Prayog in Microfinance and Women's Empowerment." Pp. 200-244 in Micro-Credit, Poverty and Empowerment: Linking the Triad, edited by Neera Burra, Joy Deshmukh-Ranadive and Ranjani K. Murthy. New Delhi, Thousand Oaks, London: SAGE Publications and UNDP.

Qudrat-I Elahi, K \& Rahman M. L. 2006. "Micro-credit and micro finance: functional and conceptual differences." Development in Practice 16 (5), 476-483.

Rankin, Katharine N. 2001. "Governing Development: Neoliberalism, Microcredit, and Rational Economic Women." Economy and Society 30(1): 18-37.

Ratha, Dilip. 2007. Leveraging Remittances for Development. The World Bank. Retrieved February 4, 2009 (http://siteresources.worldbank.org/INTPROSPECTS/Resources/3349341110315015165/LeveragingRemittancesForDevelopment.pdf).

Riaz, Ali and Basu, Subho. 2007. Paradise Lost? State Failure in Nepal. Lanham: Lexington Books.

Robinson, M. 2002. The Microfinance Revolution: Sustainable Finance for the Poor. Washington, DC: World Bank.

Rogaly, Ben, Alfonso Castillo, and Martha Romero Serrano. 2004. "Building Assets to Reduce Vulnerability: Microfinance Provision by a Rural Working People's Union in Mexico." Development in Practice 14(3):381-395.

Sankar, Kalpana. 2005. "Social Moilization and Microfinance for Women's Empowerment - Lessons from the ASA Trust." Pp. 286-321 in Micro-Credit, Poverty and Empowerment: Linking the Triad, edited by Neera Burra, Joy Deshmukh-Ranadive and Ranjani K. Murthy. New Delhi, Thousand Oaks, London: SAGE Publications and UNDP. 
Seddon, David. 2004. "South Asian remittances: Implications for development". Contemporary South Asia 13(4): 403-420.

Seddon, David, Jagannath Adhikari and Ganesh Gurung. 2002. "Foreign Labor Migration and the Remittance Economy of Nepal" Critical Asian Studies 34(1): 019-040.

Sengupta, Rajdeep and Craig P. Aubuchon. 2008. "The Microfinance Revolution: An Overview." Federal Reserve Bank of St. Louis Review 90(1): 9-30.

Shakya, Yogendra B. and Katharine N. Rankin. 2008. "The Politics of Subversion in Development Practice: An Exploration of Microfinance in Nepal and Vietnam." Journal of Development Studies 44(8): 1214-1235.

Shrestha, S. M. 2003. Microfinance in Nepal: Experiences of RMDC as an Apex Microfinance Organization. Paper presented at the International Seminar "Attacking Poverty with Microcredit" January 8-9, 2003, at PKSF (Palli KarmaSahayak Foundation), Dhaka, Bangladesh.

Simanowitz, Anton and Alice Walter. 2002. "Ensuring Impact: Reaching the Poorest while Building Financially Self-Sufficient Institution, and Showing Improvement in the Lives of the Poorest Women and Their Families." Pp. 1-73 in Pathways out of Poverty: Innovations in Microfinance for the Poorest Families, edited by Sam Daley-Harris. USA: Kumarian Press Inc.

Smith, Stephen. 2002. "Village Banking and Maternal and Child Health: Evidence from Ecuador and Honduras." World Development 30(4): 707-23.

Stoesz, David, Carles Guzzetta, and Mark Lusk. 1999. International Development. Boston: Allyn and Bacon.

Takahatake, Takashi and Keshv L. Maharjan. 2002. "An Examination of the SocioEconomic Implications of Microfinance Programs: An Alternative Approach in Nepal." Contributions to Nepalese Studies 29(1): 97-127.

Thapa, Ganesh B. 2008. The State of Microfinance: Breadth and Depth. A conference Power Point Presentation at Microfinance Summit 2008 in Nepal. Retrieved January 05, 2009 
(http://www.microfinancesummitnepal.org/papers/The $\% 20$ State $\% 20$ of $\% 20$ Microf inance $\% 20$ Depth $\% 20 \& \% 20$ Breadth\%20-\%20G\%20B\%20Thapa.ppt\#256,1,Slide 1 Retrieved on $3 / 23 / 08$ ).

Uprety, T. P. 2008. "Policy and Regulatory Issues in Microfinance." Conference paper Micro-finance Summit Nepal-2008.

Versluysen, Eugene. 1999. Defying the Odds: Banking for the Poor. Kumarian Press.

Von Pischke, J., Bennett, L. and Goldberg,M. 1993. Sustainable Financial Services for the Poor: Building on Local Capacity, Main Report, Vol. 1, Kathmandu: The World Bank.

World Bank. 2006. Global Economic Prospects: Economic Implications of Remittances and Migration 2006. Washington DC: The World Bank.

Zarate-Hoyos, German A. 2004. "Consumption and Remittances in Migrant Households: Toward a Productive Use of Remittances." Contemporary Economic Policy 22(4): $555-565$. 